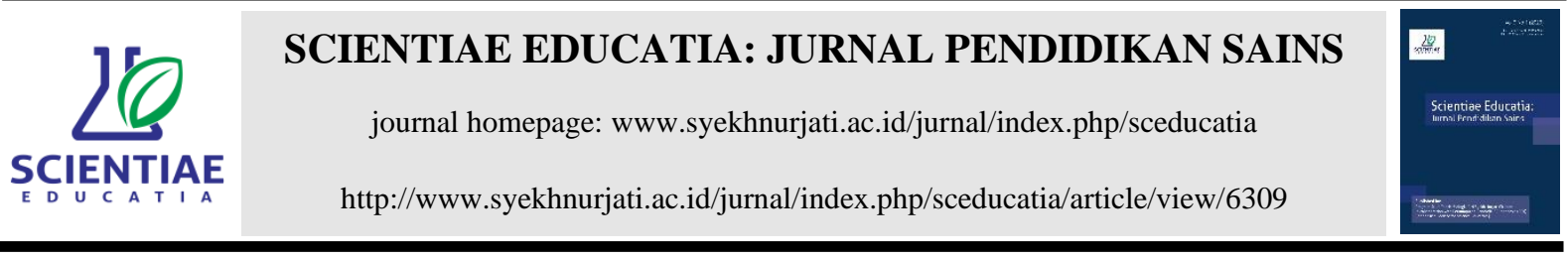

\title{
Student Discipline Towards Natural Science Learning at Secondary Schools in Muaro Jambi Regency
}

\author{
Astalini $^{\mathrm{a}^{*}}$, Dwi Agus Kurniawan ${ }^{\mathrm{b}}$, Nugroho Kurniawan ${ }^{\mathrm{c}}$ \\ a Department of Physics Education, Faculty of Teacher Training and Education, Universitas Jambi, Jambi, Indonesia \\ ${ }^{\mathrm{b}}$ Department of Physics Education, Faculty of Teacher Training and Education, Universitas Jambi, Jambi, Indonesia \\ ${ }^{c}$ Department of Physics Education, Faculty of Teacher Training and Education, Universitas Jambi, Jambi, Indonesia
}

*Corresponding author: Kecamatan Telanai Pura, Kota Jambi, Provinsi Jambi, Indonesia. E-mail addresses: astalinizakir@unja.ac.id

\begin{tabular}{|c|c|}
\hline a $r$ t $\mathbf{c}$ le info & $\mathbf{a} b \mathbf{b} \mathbf{c} \mathbf{c} \mathbf{c}$ \\
\hline $\begin{array}{l}\text { Article history: } \\
\text { Received: } 07 \text { May } 2020 \\
\text { Received in revised form: } 15 \text { May } \\
2020 \\
\text { Accepted: } 31 \text { May } 2020 \\
\text { Available online: } 15 \text { June } 2020 \\
\text { Keywords: } \\
\text { Students' discipline } \\
\text { Science education } \\
\text { Science learning } \\
\text { Character education }\end{array}$ & $\begin{array}{l}\text { Discipline towards science learning is defined as a habit that characterizes students in } \\
\text { responding to nature and science object. This study aims to analyze the students' discipline } \\
\text { toward science learning. The research using a quantitative approach, this study employed the } \\
\text { use of the survey method. From } 612 \text { students, the Random Sampling technique was used to } \\
\text { select the respondents. Thus, this study analyzed the data from } 187 \text { students of State } \\
\text { Secondary Schools in Muaro Jambi Regency. The data obtained using questionnaires. The } \\
\text { results of the study are based on the measurement of the indicators on the students' discipline } \\
\text { in science learning. The findings show that in the first indicator, } 69 \% \text { of students are } \\
\text { categorized as very good. In the second indicator, discipline in joining science lessons, } \\
35,8 \% \text { of students are categorized as very good. In the third indicator, discipline in doing } \\
\text { science tasks, } 46 \% \text { of students are categorized as good. In the fourth indicator, discipline in } \\
\text { learning science at home, } 47,1 \% \text { of students are categorized as fair. Based on these results, it } \\
\text { can be concluded that the students' discipline towards science learning is considered as } \\
\text { positive. }\end{array}$ \\
\hline
\end{tabular}

\section{Introduction}

In this 21 st century, the era of globalization, the development of science, technology, and information is increasingly fast, and there is a competition between nations (Suardana et al., 2018). The era of the 21st century marks a very rapid acceleration in many aspects of human life. One of them is a dynamic growth and renewal in the world of education. Today, education proliferates and is inherent in every individual. Without education, people will find it challenging to participate in the era of globalization actively and to seize better opportunities (Manan, 2015). Thus, every student has the right to a quality and good education. It is because education provides positive knowledge for each individual. As said by Astalini et al. (2018), education is an essential activity that can change the knowledge and behaviour of each individual to be better.

Education in the context of teaching and learning activities, which will be discussed in this study, refers to the students' ability to understand the concept of the subject matter. In the school settings, a variety of school subjects are provided including; natural science social 
sciences, sports, health sciences, and information and technology science. However, the focus of the subject matter discussed in this study will be on natural science taught at the Junior High School level. Science education is an effort to provide students with an understanding of the nature of science (Kurniawan, Astalini, \& Kurniawan, 2019). In this regard, science refers to a natural science that studies objects and processes that occur in nature (Hidayati, 2016).

However, learning activities are not merely intended to strengthen students cognitive abilities. Some other aspects must also be met, one of which is the aspect of the character (affective). Character education in learning should be mandatory to be implemented in various subject areas (Widodo \& Pranata, 2018). This aspect is believed to encourage the students' success in their learning. Character is a collection of ethical behaviour of an individual (Sudewo, 2011). It is essential for every student to have positive characters to be implemented in all matters of action. One of the characters that can positively support students in their learning activities is discipline. Self-discipline is a cycle of habits that are done repeatedly, continuously and consistently (Saleh, 2012). Discipline is highly necessary to be applied since it has a positive impact on the students' good habits towards learning.

The aspect of discipline can be applied in science education. Science is a compulsory subject that is studied in junior high schools (Astalini \& Kurniawan, 2019). It is useful to detect how students' attitudes and disciplinary behaviour towards science is not only limited to the School environment. Students' discipline on science can be defined as a reasonable and consistent effort in carrying out science learning activities and other activities on a regular and systematic basis (Astalini et al., 2019). According to Aslianda et al. (2017), there is a positive influence of the discipline on science learning. Therefore it is essential to carry out science learning along with strengthening the students' discipline.

Science learning needs special treatment because learning science is regarded by students as difficult due to the complexity of the material. Science learning, especially physics material, is mostly presented as concepts and collections of formulas that must be memorized (Bestari, Yulianti, \& Dwijananti, 2014). Science learning in schools is still challenging to learn for some students (Astuti, Widha, \& Suciati, 2012). Supported by Widyatmoko (2012) from the results of his interview with the science teacher, it was stated that many students thought that science was difficult to understand. It becomes the scourge that makes students less interested in learning science. Such an assumption about science is actually not the 
primary reason. There are some other aspects that play a role in regard, for instance, students' negative attitudes, low interest and, motivation, and low discipline in learning science.

Based on the above, it can be concluded that one of the solutions to improve students' effectiveness in learning science is to strengthen the discipline character of students. The students' discipline character can make the activities carried out run effectively and efficiently (Rusyan, 2014).

There is a positive correlation between discipline and science learning; we then carried out a study to determine the students' discipline towards science learning. The focus of this study is the student discipline on science-based on the four indicators of student discipline that are considered relevant, including: (1) discipline to attend school, (2) discipline in joining science lessons at school, (3) discipline in doing science tasks, and (4) discipline in learning science at home.

\section{Method}

This study analyzes and describes the students' discipline in science learning. The quantitative research approach is used in this study. According to Sugiono (2016), in general, quantitative research places more emphasis on the breadth of information, so this research is appropriate for a large population with limited variables. While in the process, this research adopted a survey method. Using the Survey design, researchers describe some trends, behaviours, or opinions of a population quantitatively by examining a population sample (Creswell, 2017). Later, from the implementation of the research process, the research data will be obtained to get insights into the students' discipline in leaning science.

The Population of this study were 612 students coming from three (3) State Secondary Schools in Muaro Jambi. The sample of research using simple random sampling technique, the samples of research were selected to test and analyze the students' discipline towards science. Thus, The number of research samples in this study were 187 students. The data collection technique was the total sampling method so that conclusions will be drawn from the overall number of students (187 students).

To get the data, a questionnaire was sent to all students. The questionnaire came from 2 previous research developments, the first by Masumah (2015), and the second was developed by Kurniawan (2019) specifically addressing the students' discipline in science learning. Thus the questionnaire used was "Student discipline towards science". This questionnaire measures 
the discipline of students towards the science lessons. The questionnaire consisted of 20 statements, both positive and negative statements. The measurement of the students' discipline on science learning is based on the following four indicators: (1) discipline to attend school, (2) discipline in joining science lessons, (3) discipline in doing science tasks, and (4) discipline in learning science at home.

Table 1. Indicators of student discipline towards science

\begin{tabular}{ccc}
\hline No. & Indicators & Number of statements \\
\hline 1 & Discipline to attend school & 3 \\
2 & Discipline in joining science lessons & 4 \\
3 & Discipline is doing science tasks & 7 \\
4 & Discipline in learning science at home & 6 \\
& Total & 20 \\
\hline
\end{tabular}

This study uses a Likert scale as the assessment scale on the students' questionnaire on science. There are 5 rating scales for each of these questionnaire statements. The assessment system in this questionnaire includes five assessment categories, as follows: Very Poor (VP) = 1, Poor $(\mathrm{P})=2$, Fair $(\mathrm{F})=3$, Good $(\mathrm{G})=4$, and Very Good $(\mathrm{VG})=5$. Furthermore, descriptive statistics are used in analyzing the research data. The following statistics will illustrate the students' discipline in science learning.

\section{Result and Discussion}

\section{Discipline to attend school}

The following table shows the statistics results of the students' discipline in science learning based on the first indicators: discipline to attend school. Table 2 below illustrates the categories of students' discipline in science learning.

Table 2. Discipline to attend school

\begin{tabular}{|c|c|c|c|c|c|c|c|}
\hline \multicolumn{3}{|c|}{ Classification } & \multirow{2}{*}{$\%$} & \multirow{2}{*}{$\begin{array}{c}\text { Stad. } \\
\text { deviation }\end{array}$} & \multirow{2}{*}{ Mean } & \multirow{2}{*}{ Mode } & \multirow{2}{*}{ Median } \\
\hline Range & Discipline & Amount & & & & & \\
\hline $3-5.4$ & Very Poor & 1 & 0.5 & \multirow{6}{*}{0.8} & \multirow{6}{*}{4.5} & \multirow{6}{*}{5} & \multirow{6}{*}{5} \\
\hline $5.5-7.8$ & Poor & 6 & 3.2 & & & & \\
\hline 7.9-10.2 & Fair & 12 & 6.4 & & & & \\
\hline $10.3-12.6$ & Good & 39 & 20.9 & & & & \\
\hline $12.7-15$ & Very Good & 129 & 69.0 & & & & \\
\hline \multicolumn{2}{|c|}{ Total } & 187 & 100 & & & & \\
\hline
\end{tabular}

Table 2 shows that the students' discipline to attend school is categorized as very good. As seen in table 2, it is known that 129 of 187 students (69\%) belong to a "very good" category. Besides, Table 2 also shows that 39 students (20.9\%) are categorized as "good", 12 students 
(6.4\%) belong to "fair" category, 6 students $(3.2 \%)$ are categorized as poor, and 1 student $(0,5 \%)$ belong to a "very poor" category. Based on the results above, in this indicator, the majority of students are categorized as very good.

Discipline to attend school can be interpreted as the habits and behaviour of students who are consistent with being present at school. It was seen from their attendance in school, whether they were present every day and on time. This indicator is considered necessary since students are considered to be ready to learn in class, especially science lessons if they are disciplined in attending school. Students who are disciplined and have good responsibilities to come to school (the positive character), whereas students who are not disciplined are considered to have a negative character. Disciplinary character education is very important to foster a person's character, especially students (Wuryandani, Maftuh, \& Budimansyah, 2014). The good character will also encourage students to be disciplined in learning Natural Sciences. Such positive character will lead them to be disciplined always coming to school responsibly and ready to join the learning process in class. This is reinforced by Hadianti (2008), who states that "School discipline if developed and implemented well, consistently, and consequently will have a positive impact on the lives and behaviour of students".

\section{Discipline in joining science lessons}

Table 3. below shows the results of the students' discipline in learning Natural Sciences, which are reviewed based on the second indicator: discipline in joining science lessons at school. Here are the complete results.

Table 3. Discipline in joining science lessons

\begin{tabular}{|c|c|c|c|c|c|c|c|}
\hline \multicolumn{3}{|c|}{ Classification } & \multirow{2}{*}{$\%$} & \multirow{2}{*}{$\begin{array}{c}\text { Std. } \\
\text { deviation }\end{array}$} & \multirow{2}{*}{ Mean } & \multirow{2}{*}{ Mode } & \multirow{2}{*}{ Median } \\
\hline Range & Discipline & Amount & & & & & \\
\hline $4-7.2$ & Very Poor & 0 & 0 & & & & \\
\hline $7.3-10.4$ & Poor & 16 & 8.6 & & & & \\
\hline $10.5-13.6$ & Fair & 50 & 26.7 & 0.98 & 3.9 & 5 & 4.0 \\
\hline $13.7-16.8$ & Good & 54 & 28.9 & & & & \\
\hline $16.9-20$ & Very Good & 67 & 35.8 & & & & \\
\hline \multicolumn{2}{|c|}{ Total } & 187 & 100 & & & & \\
\hline
\end{tabular}

Table 3 shows the students' discipline in joining science lessons in schools. The results of the descriptive analysis show that, in this indicator, 67 students $(35.8 \%)$ are categorized as very good. Meanwhile, the other students belong to a good category (28.9\%), a fair category (26.7\%), a bad category (8.6\%). None students are categorized as very poor. Based on the 
results, it can be concluded that in this indicator, the students' discipline is considered as good.

Discipline in joining science lessons is the positive behaviour that students should perform in the science learning process. Such behaviour is shown from their habits and habits in joining science lessons, reflected in their responsiveness, active participation, and good interest and motivation in learning science. The students' learning interest is shown from their encouragement and willingness in the learning process when they try to know and understand the material (Budiono \& Antika, 2018). Their willingness can be developed through understanding their responsibilities in joining the learning process.

Student discipline in the classroom is considered a key to effective learning and teaching (Ugurlu et al., 2015). The results of the study show that, in this indicator, 67 students $(35,8 \%)$ belong to a very good category. These results indicate the students' positive discipline in science learning, in which most of the students are actively involved and interested in the process of learning science. Reinforced by Febriana et al. (2018) Learning is said to be successful if all or some students are actively involved, physically, mentally and socially in the learning process.

\section{Discipline in doing science tasks}

Table 4 below shows the results of students' discipline Based on the third indicator discipline in doing science tasks.

Table 4. Discipline doing science tasks

\begin{tabular}{|c|c|c|c|c|c|c|c|}
\hline \multicolumn{3}{|c|}{ Classification } & \multirow{2}{*}{$\%$} & \multirow{2}{*}{$\begin{array}{c}\text { Std. } \\
\text { deviation }\end{array}$} & \multirow{2}{*}{ Mean } & \multirow{2}{*}{ Mode } & \multirow{2}{*}{ Median } \\
\hline Range & Discipline & Amount & & & & & \\
\hline $7-12.6$ & Very Poor & 1 & 0.5 & & & & \\
\hline $12.7-18.2$ & Poor & 7 & 3.7 & & & & \\
\hline $18.3-23.8$ & Fair & 43 & 23.0 & 0.83 & 3.9 & 4.0 & 4.0 \\
\hline $23.9-29.4$ & Good & 86 & 46.0 & & & & \\
\hline $29.5-35$ & Very Good & 50 & 26.7 & & & & \\
\hline \multicolumn{2}{|c|}{ Total } & 187 & 100 & & & & \\
\hline
\end{tabular}

As can be seen in table 4 , in this indicator, 86 students (46\%) belong to a "good" category. Meanwhile, the other students are categorized as "Very good" (26.7\%) (50 students), "Fair" (23\%), (43 students ), "Poor" (3.7\%), and "very poor" (0.5\%). These results show that the students' disciplines towards science learning in this indicator is considered as positive.

Discipline is doing science tasks means that every student does not have a negative dependency on doing science assignments given by his teacher (Kurniawan et al., 2019a). 
Instead, they show a positive dependence on learning science by being independent in doing science assignments. The data above show that in this indicator, 86 students (40\%) are categorized as "good". The results of this study show that the students' discipline in this indicator is positive and belongs to a "good" category. Supported by Hatfield et al. (1993), effective learning is the primary key in education because it can be a guide for students to avoid negative character when learning the content of subject matter.

\section{Discipline in learning sciences at home}

Table 5 below shows the results of students' discipline in science learning based on the fourth indicator: discipline in learning natural science at home.

Table 5. The discipline of learning natural sciences at home

\begin{tabular}{|c|c|c|c|c|c|c|c|}
\hline \multicolumn{3}{|c|}{ Classification } & \multirow{2}{*}{$\%$} & \multirow{2}{*}{$\begin{array}{c}\text { Std. } \\
\text { deviation }\end{array}$} & \multirow{2}{*}{ Mean } & \multirow{2}{*}{ Mode } & \multirow{2}{*}{ Median } \\
\hline Range & Discipline & Amount & & & & & \\
\hline $6-10.8$ & Very Poor & 0 & 0 & \multirow{5}{*}{0.87} & \multirow{5}{*}{3.4} & \multirow{5}{*}{3} & \multirow{5}{*}{3} \\
\hline $10.9-15.6$ & Poor & 23 & 12.3 & & & & \\
\hline $15.7-20.4$ & Fair & 88 & 47.1 & & & & \\
\hline $20.5-25.2$ & Good & 50 & 26.7 & & & & \\
\hline $25.3-30$ & Very Good & 26 & 13.9 & & & & \\
\hline
\end{tabular}

Table 5 shows that in this indicator, 88 out of 187 students $(47,1 \%)$ are categorized as fair. The numbers of students who belong to a good category $(26,7 \%)$ and a very good category $(13,9 \%)$ are larger than those who are categorized as very poor $(0 \%)$. Based on these results, it is concluded that the students' discipline in science learning in this indicator is considered as positive. According to Sudewo (2011), "the discipline will show the quality of a person". Thus, the students' will influence their good behaviour and a positive attitude towards science learning.

Learning is the process of interaction between students and their learning environment (Qulud, Wahidin, \& Maryuningsih, 2015). The learning environment is not only limited to school but can be anywhere outside the school. Students can develop their learning potential at home. Spending time to study at home is an important factor and has a positive impact on students' success in science learning. The discipline of learning science at home requires interest and a little time. Students are said to have interest in science if they always spend their time in activities related to science even though it is done outside the regular school time (Kurniawan et al., 2019b). This will become a habit when students regularly spend their time learning science outside the regular school time. This kind of habit is needed by every student. 
Table 5 shows that in this indicator, there are 88 students $(47,1 \%)$ who are categorized as "fair". It indicates that there are fewer students unwilling to study at home. Instead, most of the students are interested in learning science at home and consider it as essential for them too. From the research findings, it is also known that students only learn science at home when there are assignments or exams. Students spend time studying science, but not every day. This explanation concludes that there are several aspects that play a role in raising the students" willingness to learn science at home. However, whatever the reasons, we all agree that learning science at home is essential and should be done by every student. Discipline is an important aspect that must be implemented in everyday life to achieve success in everything, one of which is success in learning (Wirantasa, 2017).

\section{Conclusion}

Based on the results of this study, it can be concluded that the students' discipline towards learning Natural Science in Secondary Schools in the Muaro Jambi Regency is categorized as very good. This is evidenced by the positive results of students' discipline in all indicators (as shown in Table 2, Table 3, Table 4, and Table 5). The following are the dominant categories in each indicator of the students' discipline in learning science: in the first indicator discipline to attend school, 129 out 187 students (69\%) are categorized as very good. In the second indicator, discipline in joining science lessons, 67 out of 187 students (35.8\%) are categorized as very good. In the third indicators, discipline in doing science tasks, 86 students (46\%) belong to a "good" category. In the fourth indicator, discipline in learning science at home, 88 students $(47.1 \%)$ are categorized as fair. Based on the results, it can be concluded that the students' discipline towards science learning is considered as positive.

\section{References}

Aslianda, Z., \& Nurhaidah, N. (2017). Hubungan disiplin belajar terhadap hasil belajar siswa kelas IV Sekolah Dasar Negeri 18 Banda Aceh. Jurnal Ilmiah Mahasiswa Pendidikan Guru Sekolah Dasar, 2(1), 236- 243.

Astalini, \& Kurniawan, D. A. (2019). Pengembangan instrumen sikap siswa sekolah menengah pertama terhadap mata pelajaran IPA. Jurnal Pendidikan Sains (JPS), 7(1), 1-7.

Astalini, Kurniawan, D. A., Perdana, R. \& Kurniasari, D. (2018). Identification of student attitudes toward physics learning at Batanghari District High School. The Education Review, USA, 2(9), 475-484. 
Astalini, Pathoni, H., Kurniawan, D. A., \& Kurniawan, N. (2019). The correlation between attitudes and discipline toward the science of secondary school. Jurnal Pendidikan Sains, 7(1), 9 -14.

Astuti, R., Widha S., \& Suciati S. (2012). Pembelajaran IPA dengan pendekatan keterampilan proses sains menggunakan metode eksperimen bebas termodifikasi dan eksperimen terbimbing ditinjau dari sikap ilmiah dan disiplin belajar siswa. Jurnal Inkuiri, 1(1), 51-59.

Bestari, D., Yulianti, D. \& Dwijananti, P. (2014). Pembelajaran menggunakan SEA berbantu games untuk mengembangkan karakter siswa SMP. Unnes Physics Education Journal, 3(1), 23-29.

Budiono, A. \& Antika, L.T. (2018). Review $\pi$ : What is the description of students' interest in physics?. Jurnal Pena Sains, 5(2), 115-120.

Febriana, M., Al Asya'ari, H., Subali, B., \& Rusilowati, A. (2018). Penerapan model pembelajaran inquiry pictorial riddle untuk meningkatkan keaktifan siswa. Jurnal Pendidikan Fisika dan Keilmuan (JPFK), 4(2), 6-12.

Hadianti, L. S. (2008). Pengaruh pelaksanaan tata tertib sekolah terhadap kedisiplinan belajar siswa. Jurnal Pendidikan Universitas Garut, 2(1), 1-8.

Hatfield, E., Cacioppo, J.L., \& Rapson, R.L. (1993). Emotional contagion. Current Directions in Psychological Science, 2, 96-99.

Hidayati, N. (2016). Pembelajaran discovery disertai penulisan jurnal belajar untuk meningkatkan kemampuan kerja ilmiah siswa kelas VIII 1 SMP Negeri 1 Probolinggo. Jurnal Penelitian Pendidikan IPA, 1(2), 52-61.

Kurniawan, N. (2019). Analisis hubungan sikap siswa dan disiplin siswa terhadap mata pelajaran IPA di SMPN 11, SMPN 34, dan SMPN 38 Kabupaten Muaro Jambi. Fakultas Keguruan \& Ilmu Pendidikan. Universitas Jambi : Jambi.

Kurniawan, D. A., Astalini, \& Kurniawan, N. (2019). Sikap siswa terhadap pelajaran IPA di SMP Kabupaten Muaro Jambi Provinsi Jambi. Curricula: Journal of Teaching and Learning, 4(3), 111-127.

Kurniawan, D. A., Astalini, Kurniawa , N., \& Pathoni, H. (2019). Analisis korelasi sikap siswa dan disiplin siswa terhadap IPA pada siswa SMP Provinsi Jambi. Jurnal Pendidikan Fisika dan Keilmuan (JPFK), 5(2), 59-75

Kurniawan D. A., Astalini A, Kurniawan N \& Anggraini, L. (2019) Sikap siswa terhadap IPA berdasarkan investigasi dan korelasi: kesenangan belajar dan minat meluangkan waktu pada IPA. Science Education Journal (SEJ), 3(1), 1-13.

Ma'sumah, S. (2015). pengaruh disiplin belajar terhadap prestasi belajar siswa kelas IV Sekolah Dasar Negeri Se-Daerah Binaan II Kecamatan Petanahan Kabupaten Kebumen. Fakultas Ilmu Pendidikan. Universitas Negeri Semarang : Semarang

Manan, M. (2015). The implementation of the right to education in Indonesia. Indonesia Law Review, 1, 51-68.

Qulud, Wahidin, \& Maryuningsih, Y. (2015). Penerapan model pembelajaran learning cycle 7E untuk meningkatkan kemampuan literasi sains siswa pada konseo reproduksi kelas XI di SMA Negeri 1 Arjawinangun. Scientiae Educatia: Jurnal Pendidikan Sains, 4(1), 21-32

Rusyan, H. A. T. (2014). Membangun Disiplin Karakter Anak Bangsa. Jakarta : PT. Pustaka Dinamika 
Suardana, I. N., Redhana, I. W., Sudiatmika, A. A. I. A. R., \& Selamat, I. N. (2018). Students' critical thinking skills in chemistry learning using local culture-based 7E learning cycle model. International Journal of Instruction, 11(2), 399-412.

Sudewo. (2011). Best Practice Character Building, Menuju Indonesia Lebih Baik. Jakarta Selatan: Republika

Sugiono. (2016). Metode Penelitian Kuantitatif, Kualitatif dan Kombinasi (Mixed Methods). Bandung: Penerbit Alfabeta

Ugurlu, C. T., Beycioglu, K., Kondakci, Y., Sincar, M., Cevat, M., Yildirim, Ozer, N. \& Oncel, A. (2015). The views of teachers towards the perception of discipline in schools. Procedia- Social and Behavioral Sciences, 197(2015), 120-125.

Widiyatmoko, A. (2012). Pengembangan perangkat pembelajaran IPA dengan pendekatan physics-edutaiment berbantuan CD pembelajaran interaktif. Journal Of Primary Education, 1(1), 38-44.

Widodo, R. A. \& Pranata, M. (2018). Penerapan grafik klip dalam pendidikan karakter untuk pembelajaran sikap di sekolah menengah. Jurnal Pendidikan: Teori, Penelitian, dan Pengembangan, 3(4), 491-496.

Wirantasa, U. (2017). Pengaruh kedisiplinan siswa terhadap prestasi belajar matematika. Jurnal Formatif, 7(1), 83-95.

Wuryandani, W., Maftuh, B., \& Budimansyah, D. (2014). Pendidikan karakter disiplin di sekolah dasar. Cakrawala Pendidikan, 33(2), 286-295. 